\title{
PERAN TATA KELOLA PERBANKAN SYARIAH TERHADAP RISIKO PERBANKAN SYARIAH DI INDONESIA
}

\author{
RUDY HARTANTO \\ Universitas Islam Bandung \\ *Email: rudyhartanto05@gmail.com
}

\begin{abstract}
The increased penetration of the Islamic banking market in Indonesia is one of the highest in ASIA. The enhancement in the market has an impact on increasing the risk complexity of Islamic banking business activities. Sharia banking risks need to be managed and controlled properly in order to prevent banking failures. Bank governance (corporate governance) is indicated as one of the things that plays an important role in determining the level of risk faced by banks. The purpose of this study is to examine whether good governance can reduce the risk of Islamic banking. This study uses the population of Islamic banking from 2014-2018. The samples obtained in this study are 58 Islamic banks. The results showed that good governance can reduce the banking risk. In addition, the testing using control variables showed that the greater the size of the banking system that is proxied by the total assets, the higher the risk received by banks both from credit risk to investment risk.
\end{abstract}

Keywords: islamic banking governance, islamic banking risk, islamic banking

\section{PENDAHULUAN}

Setiap kegiatan usaha atau bisnis tidak terlepas dari resiko yang melekat pada kegiatan usahanya baik risiko yang dapat diperkirakan maupun tidak dapat diperkirakan. Perbankan Syariah yang bergerak di sektor jasa keuangan juga tidak terlepas dari risko yang dapat berdampak negatif terhadap pandangan dan permodalan bank syariah. Perkembangan perbankan syariah yang semakin pesat serta adanya inovasi produk syariah yang semakin banyak berkembangan dan diterapkan di Indonesia (Saputra, 2017) berdampak pada semakin kompleksnya risiko kegiatan usaha perbankan syariah. Islamic Financial Services Industry Stability Report 2018 menunjukkan bahwa Indonesia merupakan salah satu negara yang memiliki peningkatan penetrasi pangsa pasar di perbankan syariah tinggi di tingkat ASEA (IFSB, 2018).

Sampai dengan saat ini risiko yang wajib dikelola dan dikendalikan oleh perbankan syariah menurut Otoritas Jasa Keuangan (OJK) adalah sepuluh (10) jenis risiko yang terdiri dari risiko kredit, risiko pasar, risiko likuiditas, risiko 
operasional, risiko hukum, risiko reputasi, risiko strategik, risiko kepatuhan, risiko imbal hasil, dan risiko investasi.

Risiko kegiatan usaha perbankan syariah yang kian beragam dan memiliki risiko yang lebih besar dibandingkan dengan perbankan konvensional (Sundararajan dan Errico, 2002; Cihak dan Hesse, 2010; Beck et al, 2013; Kabir et al, 2015) semakin meningkatkan kebutuhan akan praktek tata kelola perusahaan yang sehat (Good Corporate Governance) dibidang perbankan (Sartiningsih, 2007; Ferdyant et al, 2014). Tata kelola bank (corporate governance) diindikasikan sebagai salah satu hal yang berperan penting dalam menentukan tingkat risiko yang dihadapi oleh bank, yang pada akhirnya berimbas pada imbal hasil. Tata kelola yang baik merupakan salah satu upaya untuk melindungi kepentingan stakeholder dan meningkatkan kepatuhan terhadap peraturan perundang-undangan yang berlaku serta nilai-nilai etika yang berlaku secara umum pada industri perbankan syariah (Mutmainah, 2018).

Berdasarkan Peraturan Otoritas Jasa Keuangan Nomor 65 Tahun 2016 Tentang Penerapan Manajemen Risiko Bagi Bank Umum Syariah dan Unit Usaha Syariah Pasal 3 diketahui bahwa pengawasan aktif dari Dewan Komisaris, Direksi, dan Dewan Pengawas Syariah merupakan salah satu unsur penerapan manajemen risiko perbankan syariah. Komponen lain menurut ketentuan tersebut adalah kecukupan kebijakan, prosedur, dan penetapan limit manajemen risiko; kecukupan proses identifikasi, pengukuran, pemantauan, dan pengendalian risiko serta sistem informasi manajemen risiko; dan sistem pengendalian intern yang menyeluruh. Ketidaksesuaian tata kelola bank dengan prinsip kehati hatian dan prinsip syariah menimbulkan berbagai risiko bagi industri perbankan syariah (Mutmainah, 2018).

Berdasarkan penjelasan diatas kita dapat menyimpulkan bahwa tata kelola perbankan syariah yang baik dapat menghindari perbankan dari terjadinya risiko. Penelitian sebelumnya yang menelaah risiko perbankan dan tata kelola pernah dilakukan oleh Mutmainah (2018) yang menggunakan variabel GCG dengan berfokus pada efektivitas mekanisme GCG yang meliputi Dewan Komisaris (dan komite-komite yang dibentuknya, yakni komite pemantau risiko dan komite audit), dewan direksi, dan dewan pengawas syariah. Hasil penelitian Mutmainah (2018) menunjukkan hasil bahwa jumlah rapat dewan direksi dan jumlah rapat komite pemantau risiko berpengaruh negatif pada risiko bank syariah. Jumlah rapat dewan direksi dan jumlah rapat komite pemantau risiko berpengaruh negatif pada risiko bank syariah.

Misman dan Bhatti (2010) menemukan bahwa risiko yang dimiliki oleh perbankan syariah lebih tinggi daripada perbankan konvensional. Adanya tren pembiayaan yang terus meningkat menunjukkan bahwa perbankan syariah perlu untuk mengelola risiko yang tepat untuk keberlangsungan hidup perbankan syariah dimasa depan (Misman dan Bhatti, 2010). Lebih lanjut lagi, artikel ini memberikan kontribusi untuk menyediakan informasi umum bagaimanakah peran tata kelola perbankan syariah terhadap risiko perbankan syariah. Secara khusus, tata kelola perbankan dan risiko perbankan dalam artikel ini menggunakan skor tata kelola yang telah diatur menurut Peraturan Otoritas Jasa Keuangan (POJK). 


\section{LANDASAN TEORI}

\section{Tata Kelola Perbankan Syariah}

Tata kelola perusahaan pertama kali dikenal dalam laporan Cadburry yang menyebutkan bahwa tata kelola merupakan suatu sistem di mana operasi perusahaan diarahkan dan dikendalikan dalam setiap fungsi dalam perusahaan yang masing-masing memiliki tanggungjawab baik oleh dewan direksi, pemegang saham maupun direktur. Tata kelola perusahaan jika di pandang dari segi akuntansi dan keuangan merupakan suatu cara-cara yang digunakan perusahaan untuk mendapatkan laba atas investasi mereka. FCGI mendefinisikan tata kelola perusahaan sebagai peraturan yang mengatur hal-hal yang berkaitan dengan hakhak dan kewajiban antara pemegang kepentingan intern dan ekstern lainnya (FCGI, 2000).

Penerapan tata kelola yang dilakukan oleh perbankan menganut prinsipprinsip yang terdiri atas transparansi, akuntanbilitas, responsibilitas, independensi, dan kewajaran (Komite Nasional Kebijakan Governance, 2006). Lebih lanjut lagi, penerapan tata kelola perbankan telah diatur dalam Peraturan Bank Indonesia (PBI) 11 Tahun 2009 tentang pelaksanaan Good Corporate Governance Bagi Bank Umum Syariah dan Unit Usaha Syariah. Peraturan tersebut mewajibkan perbankan syariah untuk menerapkan tata kelola perbankan yang baik dan melaporkan hasil penerapan tata kelola kepada OJK.

\section{Risiko Perbankan Syariah}

Risiko adalah potensi kerugian akibat terjadinya suatu peristiwa tertentu. Risiko perbankan menurut POJK No. 65 Tahun 2016 Tentang Penerapan Manajemen Risiko Bagi Bank Umum Syariah dan Unit Usaha Syariah yang wajib di kelola oleh perbankan terdiri dari 10 jenis risiko antara lain risiko kredit, risiko pasar, risiko likuiditas, risiko operasional, risiko hukum, risiko reputasi, risiko strategik, risiko kepatuhan, risiko imbal hasil, dan risiko investasi. Menurut International Monetary Fund (2017) risiko perbankan dibagi menjadi 7 risiko antara lain risiko kredit, risiko pasar, risiko operasional, risiko likuiditas, risiko pengembalian dan risiko komersial yang dipindahkan.

\section{METODOLOGI PENELITIAN}

\section{Populasi dan Sampel}

Populasi yang digunakan terdiri dari perbankan syariah dengan jumlah perbankan yaitu 13 perbankan. Penelitian ini menggunakan teknik purposive sampling. ini didasarkan kelengkapan data yang diperoleh untuk digunakan dalam pengujian. Data yang digunakan dalam penelitian ini merupakan jenis data sekunder yang berupa laporan tahunan perbankan syariah tahun 2014 sampai dengan tahun 2018. Laporan tahunan perbankan syariah diperoleh dari website masing-masing perbankan. Kelengkapan data dalam laporan tahunan yang dapat 
diperoleh selama tahun 2014-2018 adalah sebanyak 58 sampel penelitian. Penelitian ini bersifat unbalanced panel dengan sifat times series dan cross section.

Tabel 1. Kriteria Pengambilan Sampel

\begin{tabular}{|l|l|l|l|}
\hline No & Kriteria & $\begin{array}{l}\text { Tidak Memenuhi } \\
\text { Syarat }\end{array}$ & $\begin{array}{l}\text { Memenuhi } \\
\text { Syarat }\end{array}$ \\
\hline 1 & $\begin{array}{l}\text { Laporan tahunan perbankan syariah yang } \\
\text { diperoleh selama 5 tahun (2014-2018) }\end{array}$ & - & 65 \\
\hline 2 & $\begin{array}{l}\text { Tidak mempublikasikan nilai peringkat } \\
\text { tata kelola dan risiko perbankan }\end{array}$ & $(7)$ & 58 \\
\hline \multicolumn{2}{|l|}{ Total Sampel (2014-2018) } & $(7)$ & 58 \\
\hline
\end{tabular}

sumber: data diolah, 2019

\section{Definisi Operasional Variabel Variabel Dependen}

Penelitian ini menggunakan variabel dependen berupa skor risiko perbankan syariah. Pengukuran skor risiko perbankan syariah merupakan hasil penilaian atas 8 (delapan) jenis Risiko yang dinilai oleh Bank. Skor penilaian sendiri (self assessment) merupakan bagian dari laporan profil risiko perbankan yang diwajibkan dalam POJK Nomor 65 Tahun 2016 Tentang Penerapan Manajemen Risiko Bagi Bank Umum Syariah dan Unit Usaha Syariah. Skor risiko perbankan syariah yang digunakan diukur dengan skala ordinal dari angka 1 sampai dengan angka 5. Penjelasan skala ordinal dari skor risiko perbankan syariah dalam penelitian ini adalah sebagai berikut:

BR = 1 "sangat rendah"; 2 "rendah"; 3 "cukup"; 4 "tinggi"; 5 " sangat tinggi"

\section{Variabel Independen}

Variabel independen dalam penelitian ini berupa penerapan tata kelola perbankan syariah. Pengukuran tata kelola perbankan syariah merupakan skor tata kelola perbankan yang dinilai oleh bank. Skor penilaian sendiri (self assessment) merupakan bagian dari laporan tata kelola perbankan yang diwajibkan dalam Peraturan Bank

Indonesia (PBI) 11 Tahun 2009 tentang pelaksanaan Good Corporate Governance Bagi Bank Umum Syariah dan Unit Usaha Syariah.

Pengukuran GCG dalam penelitian sesuai dengan penelitian Hartanto dan Purnamasari (2019) di mana semakin tinggi skor maka tata kelola semakin baik. Skor tata keola perbankan yang digunakan diukur dengan skala ordinal dari angka 1 sampai dengan angka 5. Penjelasan skala ordinal dari skor tata kelola perbankan dalam penelitian ini adalah sebagai berikut:

GCG = 5 "Sangat baik"; 4 "baik"; 3 "cukup baik"; 2 "kurang baik"; 1 "tidak baik"

Masing-masing variabel kontrol tersebut dijelaskan dengan pengukuran sebagai berikut: 
Umur Perbankan (UP) = Lama berdirinya perbankan tahun $\mathrm{t}$

Ukuran Perbankan (SIZE) $=$ Total aset perbankan tahun $\mathrm{t}$

Kinerja Perbankan (PERF)= Return on Asset (ROA) tahun $t$

\section{Teknik Analisis}

Metode analisi yang digunakan berupa analisis regresi ordinal. Penelitian ini melakukan proses pengolahan data dengan menggunakan SPSS 21. Model yang digunakan pada penelitian ini adalah sebagai berikut:

$B R=\beta_{0}+\beta_{1} G C G+\beta_{2} U P+\beta_{3} S I Z E+\beta_{4} P E R F+\varepsilon$

$\mathrm{BR}=$ Risiko Perbankan Syariah

GCG = Tata Kelola Perbankan Syariah

UP = Umur Perbankan Syariah

SIZE $=$ Ukuran Perbankan Syariah

$\mathrm{PERF}=$ Kinerja Keuangan Perbankan Syariah

\section{HASIL PENELITIAN DAN PEMBAHASAN}

\section{Statistik Deskriptif}

Tabel 2. Statistik Deskriptif

\begin{tabular}{|l|l|l|l|l|}
\hline Variabel & N & Minimum & Maximum & Mean \\
\hline BR & 58 & 1.0 & 3.0 & 2.172 \\
\hline GCG & 58 & 3.0 & 5.0 & 3.914 \\
\hline UP & 58 & 4.0 & 63.0 & 34.517 \\
\hline SIZE (jutaan) & 58 & 661.912 & 98.341 .116 & 21.764 .571 \\
\hline PERF & 58 & $-20.13 \%$ & $12.40 \%$ & $0.1493 \%$ \\
\hline Keterangan: GCG= Good Corporate Governance; UP= lama berdirinya perbankan; \\
SIZE = ukuran perusahaan; PERF= Kinerja Keuangan (ROA); BR= Risiko Perbankan
\end{tabular}

sumber: data diolah, 2019

Statistik deskriptif yang terdapat pada tabel 2 menunjukkan bahwa rata-rata tingkat skor risiko perbankan di Indonesia adalah "2" yang menunjukkan bahwa perbankan di Indonesia memilliki risiko perbankan yang rendah. Tata kelola

* Corresponding author's e-mail: rudyhartanto05@gmail.com

http://openjournal.unpam.ac.id/index.php/JIA 
perbankan syariah (GCG) menunjukkan hasil bahwa minimal skor adalah 3 dan maksimal skor adalah 5 serta rata-rata skor adalah 3. Hasil tersebut menunjukkan bahwa tata kelola perbankan syariah sudah baik dan tidak ada perbankan syariah yang menunjukkan tata kelola yang buruk. Umur perusahaan menunjukkan ratarata sebesar 34 tahun dengan minimal umur yaitu 4 tahun dan umur tertinggi adalah 63 tahun. Hal tersebut menunjukkan bahwa perbankan di Indonesia akan terus mengalami pertumbuhan dari tahun ke tahun.Tingkat aset (SIZE) menunjukkan rata-rata adalah 21 Milliar. Pada nilai minimum ROA pun mengalami nilai minus dengan nilai sebesar $-20,13 \%$ dan nilai maksimum sebesar $12,40 \%$ dengan nilai rata-rata sebesar $0,14 \%$. Dari nilai ROA dapat diambil kesimpulan bahwa masih terdapat kerugian yang dialami oleh perbankan. Sedangkan umur perbankan jika dilihat dari nilai minumum yang sebesar 4 tahun dan maksimum sebesar 193 tahun dengan rata-rata sebesar 43 tahun.

\section{Analisis Regresi Berganda}

Tabel 3. Analisis Regresi Berganda

\begin{tabular}{|c|c|c|c|c|c|}
\hline \multirow{2}{*}{\multicolumn{2}{|c|}{ Model }} & \multirow{3}{*}{\begin{tabular}{|l|}
$\mathrm{T}$ \\
6.996
\end{tabular}} & \multirow{3}{*}{\begin{tabular}{|l|} 
Sig. \\
.000
\end{tabular}} & \multicolumn{2}{|c|}{ Collinearity Statistics } \\
\hline & & & & \multirow{2}{*}{ Tolerance } & \multirow[t]{2}{*}{ VIF } \\
\hline \multirow{5}{*}{1} & (Constant) & & & & \\
\hline & GCG & -11.749 & $.000^{*}$ & .804 & 1.244 \\
\hline & UP & 1.127 & .265 & .880 & 1.137 \\
\hline & PERF & -.198 & .844 & .820 & 1.220 \\
\hline & SIZE & 1.969 & $.054 * *$ & .896 & 1.116 \\
\hline \multicolumn{6}{|c|}{ Runs Test $=0,05 ;$ One Sample KS test $=0,117 ;$ Sig model fit $=0,000 ; \mathrm{R}$ Square $=0,76$} \\
\hline \multicolumn{6}{|c|}{$\begin{array}{l}\text { Keterangan: *Sig <5\%; ***Sig <10\%; GCG= Good Corporate Governance; UP= lama } \\
\text { berdirinya perbankan; SIZE = ukuran perusahaan; PERF= Kinerja Keuangan; BR= Risiko } \\
\text { Perbankan }\end{array}$} \\
\hline
\end{tabular}

Hasil analisis regresi pada tabel 3 diatas menunjukkan bahwa signifikansi model penelitan pada taraf 5\% (sign 0,000). Hal tersebut menunjukkan bahwa model dalam penetian ini sesuai dengan data empiris atau model layak untuk digunakan. Nilai R-Square menunjukkan nilai sebesar 0,76 atau $76 \%$. Nilai tersebut menunjukkan bahwa variabel independen mampu menjelaskan variabel dependen sebesar $76 \%$ dan sisanya sebesar $24 \%$ dipengaruhi oleh variabel lain.

Hasil analisis regresi pada penelitian ini jika dibandingkan dengan hipotesis dalam penelitian ini menunjukkan bahwa variabel GCG sesuai dengan hipotesis yang telah diuraikan. Variabel GCG menunjukkan pengaruh negatif dan signifikan pada level < 1\% (sig. 0,000). Variabel kontrol dalam penelitian ini yang menunjukkan pengaruh signifikan pada level $<10 \%$ adalah hanya SIZE sedangkan UP dan PERF tidak menunjukkan pengaruh signifikan pada level < $10 \%$. 


\section{Pembahasan}

Hasil penelitian pada hipotesis ini menujukkan menujukkan hasil bahwa tata kelola perbankan yang semakin baik akan menurunkan tingkat risiko perbankan. Hasil tersebut telah sejalan dengan penelitian Mutmainah (2018). Selain itu, variabel kontrol dalam penelitian ini yang menunjukkaan hasil yang signifikan adalah ukuran perbankan yang berarti semakin besar ukuran perbankan yang diproksikan dengan total aset maka semakin besar kemungkinan risiko yang ada di perbankan. Variabel kontrol berupa umur perbakan dan kinerja keuangan perbankan tidak menunjukkan pengaruh yang signifikan.

\section{KESIMPULAN}

Penelitian ini dapat diambil kesimpulan bahwa perbankan syariah penting untuk menerapkan tata kelola yang baik guna mengelola dan mengendalikan risiko perbankan syariah yang semakin beragam sejalan dengan perkembangan perbankan syariah. Hasil penelitian juga menunjukkan bahwa perbankan syariah sudah menerapkan tata kelola yang baik dihampir seluruh perbankan syariah yang ada di Indonesia.

\section{DAFTAR PUSTAKA}

Beck, T., Demirgüç-Kunt, A., \& Merrouche, O. (2013). Islamic vs. conventional banking: Business model, efficiency and stability. Journal of Banking \& Finance, 37, 433-447

Cihak dan Hesse. (2010). Islamic banks and financial stability: An empirical analysis. Journal of Financial Services Research, 38, 95-1

Ferdyant, Ferly, Ratna Anggraini ZR, dan Erika Takidah. (2014). Pengaruh Kualitas Penerapan Good Corporate Governance dan Risiko Pembiayaan terhadap Profitabilitas Perbankan Syariah. Jurnal Dinamika Akuntansi dan Bisnis, 1(2), 134-149.

Hartanto dan Purnamasari. (2019). The Analysis of Banking Governance in Indonesia: the Financial Services Authority Perspective. ACCRUALS, 3(1), $32-48$.

International Monetary Fund. (2017). Insuring financial stability in countries with Islamic banking. Retrieved from http://www.imf.org/en/Publications/Policy-Papers/Issues/2017/02/21/ PPEnsuring-Financial-Stability-in-Countries-with-Islamic-Banking

Kabir, M. N., Worthington, A., dan Gupta, R. (2015). Comparative credit risk in Islamic and conventional bank. Pacific-Basin Finance Journal, 34, 327353. 
Misman, F. N. \& Bhatti, I. (2010). Risks exposure in Islamic banks: A case study of Bank Islam Malaysia Berhad (BIMB). In Australian Centre for Financial Studies-Finsia Banking and Finance Conference.

Mutmainah, S. (2018. Tata Kelola Dan Risiko Bank Syariah Di Indonesia Periode 2008-2016. Jurnal Akuntansi Dan Auditing, 14(2), 172-194.

Saputra, M. N. A. (2017). Kegiatan Usaha Perbankan Syariah Di Indonesia. Jurnal Masharif al-Syariah: Jurnal Ekonomi dan Perbankan Syariah, 2(1).

Sartiningsih. (2007). Penerapan manajemen risiko untuk mendukung pelaksanaan Good Corporate Governance:: Studi kasus PT Bank Mandiri (Persero), Tbk (Doctoral dissertation, Universitas Gadjah Mada).

Sundararajan, V., \& Errico, L. (2002). Islamic Financial Institutions and Products in The Global Financial System: Key Issues in Risk Management and Challenges Ahead. IMF Working Paper, 02 (192) 